\title{
The importance of store attributes on University students ‘ Clothing store selection
}

\author{
Makgopa, SS \\ Directorate: University Teaching and Learning Development \\ University of South Africa
}

\section{Keywords}

Store attributes, store image, store choice, behaviour, young consumers, university student, convenience sampling

\begin{abstract}
The purpose of this research was to investigate the criteria that university students follow in selecting clothing retail stores to shop from, focusing on the importance of store attributes. As clothing retail stores face tough competition, an understanding of the criteria for store attributes that students use for the selection of clothing retail stores would give these stores a competitive edge over rivals. As a result, a survey was conducted among university students at two shopping centres, one in the City of Tshwane and one in the City of Johannesburg, South Africa. The convenience sampling method was used in the study and statistical analysis in the form of descriptive statistics and parametric tests were used to analyse primary data. The quantitative data was analysed with the SPSS Version 23 software package. Internal consistency reliability of the measurement scales assessing university students' criteria for the selection of clothing retail stores was calculated by using Cronbach's alpha values. The most important criteria that students consider when choosing a clothing retail store are based on clothing retail stores' internal attributes such good brand names offered in store, quality products, and the variety of products in the clothing retail stores and environmental cleanliness of the store. The findings of this study further uncovered that a high percentage of students bought clothing from the following clothing retail stores: Mr Price, Identity, Truworths, Markhams and Edgars. Recommendations to stakeholders and future research directions are provided in this paper.
\end{abstract}

Corresponding author: Makgopa, SS

Email addresses for corresponding author: makgoss@unisa.ac.za

First submission received: $27^{\text {th }}$ September 2017

Revised submission received: 10 $10^{\text {th }}$ December 2017

Accepted: $22^{\text {nd }}$ December 2017

\section{Introduction}

Statistics indicate that the total students registered at higher learning institutions, specifically universities, in South Africa is high. Currently, the students registered at higher learning institutions has increased in from 1103639 students in 2013 to 1111712 students in 2014, compared to less than 500000 in the past decades (Department of Higher Education and Training, 2015). The South African government plans to increase student enrolment in public higher learning institutions to 1620000 by 2030, which will increase student enrolments by $3.5 \%$ on average per year. The higher learning institution students represent a lucrative market, because when they leave their parental homes to study at higher learning institutions, they reside at university residences or in private residences and must buy necessities such as clothes, shoes, bags, cell phones and other household necessities such as bedding. They buy different brands of clothing for themselves during their stay at university and become part of the youth market, which is an attractive market segment that become the new target market for advertisers and marketers due to their increasing buying power (Student Village, 2015). Young people who are part of the youth market, aged between 15 and 35 years, constitute over $50 \%$ of the total South African population (Statistics South Africa, 2015). According to Student Village's recent annual survey (2016), student's spending power exceeds that of their parents, since they spent R5.5billion in 2015.Students spent an average of R2 702 per month in 2015 and the market is estimated to have a potential of R30.4billion per year, which is spend on technology and other necessities such as clothing. Therefore, clothing retailers cannot ignore the student 
market and they need to understand why students buy - and what influences their choice of a clothing retail store - so that they can tailor their products and services accordingly.

The next section provides an overview of the clothing retail industry in South Africa.

\section{Overview of the clothing retail industry in South Africa}

The South African clothing retail industry is a highly diverse and mature sector with an important role to play as an employer in the country. The clothing retail industry contributes around $8 \%$ to the gross domestic product (GDP) (Statistics South Africa, 2016) and is characterised as one of the most labourintensive segments in South Africa, with more than five million employees.

According to Statistics South Africa (2014), the clothing retail sector has displayed significant growth over the past years and reached a peak of R12.7 billion in 2005 and then decreased significantly in 2006 to R11. 2billion.Thereafter, between 2007 and 2012, the market appears to have stabilised at between R11.7 billion and R11.8billion. The growth spurt of 2013 (reachingR13.5billion) could be attributed to government's commitment to strengthening the industry and aggressive marketing by clothing retail stores, and in 2014 there was a further growth of 3.5\%. The clothing retail stores in South Africa include Woolworths, Truworths, Miladys, Legit, Foschini, Edgars, Exact, Markhams, Ackermans, Identity, PEP, Mr Price. The major players in sportswear retailing are Totalsport and Sport scene, and major retailers in clothing, footwear and leather goods are Edcon Proprietary Limited (Ltd) and Woolworths Holding Ltd (Gauteng Quarterly Bulletin, 2012).

The next section provides the literature review of previous studies conducted on store attributes.

\section{Literature review}

The importance of store attributes in the clothing retail store selection has been published. As clothing retail stores face competition from both local and international stores, they must find ways to attract and retain their existing consumers. To retain customers, clothing retail stores must understand the attributes that are important to their target market and must improve the existing store attributes. Visser, Du Preez and Van Noordwyk (2006:242) postulated that creating a positive store image is crucial for clothing retail stores to differentiate itself from competitors, because consumers tend to use store image as a criterion for store selection. The preceding studies have uncovered that there is a relationship between store image attributes and store selection (Thang \& Tan, 2003; Visseret al., 2006; Cornelius, Natter and Faure, 2010). However, some studies on store attributes have focused on consumer response to store attributes including store interiors (Mari \& Poggesi, 2013; Spence, Puccinelli, Grewal and Roggeveen, 2014). Despite the mentioned studies, most recently, Johnson, Banks, Smith and Seo (2016) investigated the influence of clothing store attributes on clothing store preference and clothing benefits sought for African-American female college students, this study confirmed that the types of clothing that clothing retail stores offer are important store attributes for female students in store selection, store preference and benefit sought. According to Hernant (2009:155), consumers evaluate a group of stores according to a set of attributes and patronise the best stores, depending on their individual preferences, and these store attributes include all the attributes of a store as perceived by consumers because of their experience of the store; attributes are part of the overall image of the store. Hernant (2009:156) added that it becomes necessary for retail stores to understand what consumers are looking for when selecting a retail store and then position themselves according to the attributes that are most important to consumers.

Cornelius et al. (2010:144) argued that the selection of a store involves a comparison process whereby consumers evaluate various store attributes in terms of the overall perception of the store (store image), leading them either to select or reject a store. Cornelius et al. (2010:145) further argue that retail stores can use the manipulation of stores' external atmospheric attributes to differentiate themselves in a competitive marketplace. However, Hernant (2009:156) argued that the degree of correspondence between these stores 'atmospheric attributes and consumers' perceptions of these stores 'atmospheric attributes determines if the consumers will choose a specific store. The store environment is especially significant to the millennial consumer. Vermaak and De Klerk (2017:11) support this view by pointing out that consumers, including young customers, tend to spend more time in a clothing retail store, which resulted in increased expenditure on fashion items on a yearly basis. 
Yip, Chan and Poon (2012) explored the common attributes of the physical retail outlets favoured by Hong Kong youths to determine the relative importance for the retail marketing mix in targeting this consumer segment. The results revealed that the attractiveness of these stores was mainly determined by the product offerings in the store, service quality, price and location. The behaviour of the retail staff also influenced this market segment. Jordaan, Ehlers and Grove (2011) explored the credibility of traditionalmedia advertising versus new-media advertising; the credibility of broadcast-media advertising versus print-media advertising; the credibility of cell phone advertising versus internet advertising; and the relationship between the credibility of internet advertising and the likelihood of Generation Y consumers shopping online. The study found that Generation Y consumers rated the credibility of traditional media higher than new media and that print media had higher credibility ratings than broadcast media. Another study (Bevan-Dye et al., 2012) investigated the extent to which black Generation Y students exhibited status consumption, materialism and consumer ethnocentrism tendencies, as well as the relationship between these three constructs. The study revealed that there was a strong positive relationship between the constructs of materialism and status consumption. However, no significant relationship was found between the constructs of materialism and status consumption and that of consumer ethnocentrism.

Some studies, such as that by Mari and Poggesi (2013), investigated the attitudes and beliefs of male and female consumers in a retail context. The results revealed that female consumers rated consistent pricing as the most important criterion, followed by competitive prices and low prices. Spence et al. (2014) investigated how the organisation should design its multisensory atmospherics inside the store to ensure a higher return on investment by reviewing the scientific evidence related to visual, auditory, tactile and gustatory aspects of the store environment and their influence on consumer behaviour. According to this study, store atmospherics exert a significant influence on consumer behaviour. An increasing body of evidence shows that modern consumers engage with sensory marketing and an experienced economy. Various visual, auditory, olfactory, tactile and gustatory atmospherics affect consumers' perceptions and behaviour; their combined influence is likely even higher than that of the individual's spects. Khraim Khraim, 1-Kaidah and Al-Qurashi (2011) investigated the consumers' evaluation of retail store attributes. The findings revealed that from the six retail store attributes of consideration (locational convenience, service, post-purchase services, product offerings, affiliation and local goods), the most important factor for consumers was product offerings, with cheaper prices scoring the highest mean from among four different items. In addition, the findings showed that there was a difference between consumers' evaluation of store attributes in terms of their importance. Mortimer and Clarke (2011) explored how consumer's evaluated store attributes according to gender. They found that males consider internal attributes, such as cleanliness of the store, as more important than external attributes, such as easy access to parking, which females rated as more important. Males were found to be goal oriented, whereas female consumers valued uniqueness, assortment seeking and social interaction. Mower, Kim and Childs (2012) investigated the influence of external atmospheric variables, particularly the effect of window displays and landscaping on customers' responses to a clothing retail boutique. The results uncovered that window displays and landscaping had little effect on consumers 'pleasure or arousal. However, window displays, and landscaping did influence whether the consumers approved of the store exterior and their subsequent patronage intentions.

Since most students are young people, they are an important market for various product categories. Therefore, it is important for clothing retail stores to understand what motivates the youth to shop where they do. The behaviour of young consumers differs from that of older generations (Twenge \& Campbell, 2008). While many research studies have been conducted on youth and students in general (Bevan-Dye et al., 2012; Mafini, Dhurup \& Mandhlazi, 2014) and some on female students (Johnson et al., 2016), none have focused on attributes considered by the youth market comprising mostly university students when evaluating clothing retail stores and with exclusive focus on the South African economy. This is even though the South African youth market spends more than R8 billion on clothing, food and groceries yearly (Student Village, 2016). Nevertheless, some studies have focused on social media usage by the youth (Jordaan, Ehlers \& Grove 2011) and shopping styles (Mafiniet al., 2014). 
Considering the preceding studies, there is a gap in the literature regarding the youth market, specifically university students' selection criteria of store attributes in the South African context. Therefore, this study attempted to fill the gap in the literature regarding the youth market, specifically university students, and the selection criteria they use to select clothing retail stores from which to purchase clothes with more focus on store attributes.

The next section outlines the purpose of this research study.

\section{Research purpose}

The purpose of this research was to examine the selection criteria, specifically store attributes that university students consider when deciding which clothing retail store to buy from. The next section outlines the research methodology followed to realise the research objectives of this study.

\section{Research methodology}

This section outlines the research methodology that was used to achieve the research purpose of this study, including the research design and data collection method, the target population, the sampling technique and the data analysis method.

\subsection{Research design and data collection method}

To examine the store attributes that university students consider as criteria when selecting which clothing retail store to buy from, a quantitative research approach was used to gather primary data. The positivist research philosophy was followed in this study. Positivist has a long history in philosophy of science and it arose from the nine-tooth century by Frenchman (1798-1857). Positivist researchers seek rigorous exact measures and objective research, test hypotheses often use experiments, surveys, and statistics (Neuman, 2011). This implies that positivist favours quantitative research. This study was conducted in June 2015, during shopping hours at the two regional shopping malls in Gauteng Province, South Africa. Gauteng Province was selected due to the number of citizens staying in the province - $24 \%$ of the 54.96 million people living in this province, and it is estimated that the province accounts for $35 \%$ of the country's GDP and 40\% of employment (Department of Trade and Industry, 2016).

\subsection{Target population}

The target population in the study consisted of adult visitors to the Brooklyn and Northgate shopping centres in Gauteng Province, South Africa. Three hundred and eight (308) adult shoppers at the two shopping centres participated in the study. For this study, adults were defined as male and female individuals aged 18 years and older of all cultural and racial backgrounds, who visited the clothing retail stores at the two shopping centres in June 2016. The age group 18 to 34 was selected as it represented most of the youth market in South Africa that are registered at higher learning institutions. The respondents participated in this study indicated experience and knowledge in answering questionnaires.

\subsection{Sample technique}

A non-probability quota sampling plan was used in the study, with quotas being filled based on the convenience and personal judgement of the researcher. The first stage of the quota sampling involved compiling the demographics of respondents in terms of age and gender. During this stage, respondents were categorised into two age groups, namely 18-24 years and 25-34 years, both males and females. In addition, economic activity or employment status of respondents was considered; for example, considering whether students were full-time or part-time students with part-time job or not was considered. The second stage was the convenience sampling, which involves the selection of readily available respondents (Cooper \&Schindler, 2011:179). Convenience sampling was used in this study because it is less expensive and less time-consuming than other sampling methods and because there was no available sample frame.

\subsection{Measurement scales used on the questionnaire}

To compile a scale of measurement for students' perceptions of store attributes, questionnaire items were adapted from previous studies by Khraim, Khraim, Al-Kaidahand Al-Qurashi (2011) and Mortimer and Clarke (2011). Respondents indicated the extent to which they agreed with the statements on a five-point scale, where 5 means strongly agree and 1 means strongly disagree. The respondents were 
also requested to provide demographic data regarding their age, gender and race. The draft questionnaire was pretested by using a convenience sample of 12respondents of different age groups and gender who visited Brooklyn Shopping Centre to shop at retail clothing stores. Thereafter, it was deemed unnecessary to adjust the draft questionnaire as respondents reported no problems in answering it. The selfadministered questionnaires were able to be completed in 20 minutes or less. No incentives were given to respondents for their participation in this study.

\subsection{Data analysis}

Descriptive statistics were used in this study to analyse the primary data on demographic variables of respondents and clothing retail store attributes. The Statistical Package for Social Science (SPSS version 23) was used to capture data automatically on handheld devices and to analyse these data. The data were of good quality as there were no missing values. The reliability of the measurement scale was assessed by measuring internal consistency by using Cronbach's alpha values. Cronbach's alpha is used to measure the internal consistency reliability, which is the average of all possible split-half coefficients resulting from different splitting of scale items (Malhotra, 2010). The validity of the measurement scale was assessed by considering face validity or content validity and by using a scale that proved to be valid in previous studies.

\subsection{Variables used in data analysis}

In line with the overall research objectives of the study, table 1 depicts the variables (age, gender, economic activity, frequency of visits, relative popularity of clothing retail store and clothing retail store attributes) analysed during the data analysis.

Table 1: Variables used in the data analysis

\begin{tabular}{|l|l|l|}
\hline \multicolumn{1}{|c|}{ Variable name } & \multicolumn{1}{|c|}{ Level of measurement } & Univariate descriptive statistics \\
\hline Age & Nominal scale & Percentages, mode \\
\hline Gender & Nominal scale & Percentages, mode \\
\hline Economic activity & Nominal scale & Percentages, mode \\
\hline $\begin{array}{l}\text { Frequency of visits to the clothing } \\
\text { retail store }\end{array}$ & Nominal scale & Percentages, mode \\
\hline Clothing retail store attributes & Interval scale & Range, mean, standard deviation \\
\hline $\begin{array}{l}\text { Relative popularity of clothing } \\
\text { retail store }\end{array}$ & Nominal scale & Percentages, mode \\
\hline
\end{tabular}

\subsection{Reliability and validity}

This subsection indicates that the internal consistency reliability of the measurement scales measuring shopper satisfaction, loyalty and shopping motives were assessed by calculating Cronbach's alpha values. A Cronbach's alpha value of 0.6 or higher indicates that the measurement scale is reliable (Malhotra, 2010). All Cronbach's alpha values exceeding 0.6 indicate internal consistency reliability for all measurement scales.

\section{The contribution of the study}

This study provides a significant means of evaluating and understanding marketing strategies in relation to the youth segment, specifically university students. In South Africa, the youth culture changes frequently as new technologies, attitudes and fashions emerge. This study is valuable in understanding the buying behaviour of this segment of the market regarding the clothing retail stores from which they purchase. This study further provides value to literature in retail context, specifically on consumer behaviour, and further provides directions for future research areas.

The next section presents the results of this study. 


\section{Findings}

Table 2: Demographic profile of respondents

\begin{tabular}{|c|c|c|}
\hline Gender & Number (N) & Percentage (\%) \\
\hline Male & $\mathbf{1 4 8}$ & $\mathbf{4 8 . 1}$ \\
\hline Female & $\mathbf{1 6 0}$ & $\mathbf{5 1 . 9}$ \\
\hline Total & $\mathbf{3 0 8}$ & $\mathbf{1 0 0}$ \\
\hline Age group & $\mathbf{N}$ & $\mathbf{5 8 . 4}$ \\
\hline 18 to 24 years & $\mathbf{1 8 0}$ & $\mathbf{4 1 . 6}$ \\
\hline 25 to 34 years & $\mathbf{1 2 8}$ & $\%$ \\
\hline Economic activity & $\mathbf{N}$ & $\mathbf{5 . 8}$ \\
\hline Student (part-time) and not working & $\mathbf{1 8}$ & $\mathbf{1 9 . 5}$ \\
\hline Student (part-time) and working & $\mathbf{6 0}$ & $\mathbf{6 8 . 2}$ \\
\hline Student (full-time) and not working & $\mathbf{2 1 0}$ & $\mathbf{6 . 5}$ \\
\hline Student (full-time) and working & $\mathbf{2 0}$ & \\
\hline
\end{tabular}

Table 2 shows that most respondents were female (51.9\%); male respondents accounted for $48.1 \%$. Most respondents (58.4\%) fell within the 18-24years age group and the minority $(41.6 \%)$ fell within the 25-34 years age group. Table 2 illustrates the economic activities of the respondents: The majority were full-time students who were not working $(68.2 \%)$, followed by part-time students who were working $(19.5 \%)$. The minority of respondents were part-time students who were not working (5.8\%) and full-time students who were working $(6.5 \%)$.

Table 3: Frequency of visits to clothing retail stores

\begin{tabular}{|c|c|c|}
\hline & $\mathbf{N}$ & $\%$ \\
\hline More than once a week & 74 & 24.0 \\
\hline Once a week & $\mathbf{7 9}$ & $\mathbf{2 5 . 4}$ \\
\hline Twice a month & $\mathbf{9 4}$ & 30.5 \\
\hline Once a month & 62 & 20.1 \\
\hline Total & 308 & 100 \\
\hline
\end{tabular}

Table 3 indicates that most respondents (30.5\%) visited the clothing retail stores of their choice twice a month, while the minority $(20.1 \%)$ visited them once a month.

Table 4: Clothing retail store attributes

\begin{tabular}{|c|c|c|}
\hline Attributes & Mean (M) & Standard deviation (SD) \\
\hline Friendliness of staff & 4.21 & 0.831 \\
\hline Offers a variety of products & 4.34 & 0.717 \\
\hline Provides quality services & 4.25 & 0.762 \\
\hline Sells quality products & 4.40 & 0.690 \\
\hline Offers fashionable products & 4.32 & 0.761 \\
\hline Offers good brand names & 4.41 & 0.736 \\
\hline Offers reduced prices regularly & 3.84 & 1.026 \\
\hline Conveniently located & 4.26 & 0.932 \\
\hline Products are easily accessible in the & 4.27 & 0.943 \\
\hline store & 4.30 & 0.925 \\
\hline Convenient business hours & 4.19 & 0.970 \\
\hline Offers convenient service & 4.30 & 0.784 \\
\hline Environmental cleanliness of the store & 3.55 & 1.117 \\
\hline Pleasant atmosphere & 4.22 & 0.773 \\
\hline
\end{tabular}

Table 4 shows that respondents agreed the most with the statements "Offers good brand names" (mean=4.41), "Sells quality products" (mean=4.40), "Offers a variety of products" (mean=4.34) and "Offers fashionable products" (mean=4.32). Environmental cleanliness of store was also higher (mean=4.30). The 
respondents agreed the least with the statements "Pleasant atmosphere" (mean=3.55) and "Offers reduced prices regularly" (mean=3.84) the standard deviation (SD) for the statements ranges from 0.736 to 1.117.

Table 5: The relative popularity of clothing retail stores

\begin{tabular}{|l|c|l|}
\hline \multicolumn{1}{|c|}{ CLOTHING RETAIL STORE } & RELATIVEPOPULARITYOF CLOTHING RETAIL STORES \\
\hline Truworths & $\mathbf{N}$ & $\%$ \\
\hline Woolworths & $\mathbf{2 9}$ & $\mathbf{1 1 . 6}$ \\
\hline Markhams & 35 & $\mathbf{9 . 4}$ \\
\hline Mr Price & 65 & $\mathbf{1 1 . 4}$ \\
\hline PEP & 19 & $\mathbf{2 1 . 1}$ \\
\hline Identity & 36 & 6.2 \\
\hline Edgars & 31 & $\mathbf{1 1 . 7}$ \\
\hline Foschini & 7 & 10.1 \\
\hline Exact & 5 & 2.3 \\
\hline Legit & 10 & 1.6 \\
\hline Miladys & 3 & 3.2 \\
\hline Sportscene & 16 & 0.9 \\
\hline Uzzi & 6 & 5.2 \\
\hline Totalsports & 10 & 1.9 \\
\hline
\end{tabular}

Table 5 shows that most respondents selected Mr Price (20.1\%), followed by Identity $(11.7 \%)$, Truworths (11.6\%), Markhams (11.4\%) and Edgars (10.1\%) as their favourite (preferred) clothing retail stores. Miladys $(0.9 \%)$ and Exact $(1.6 \%)$ were the least popular retail clothing stores among the respondents. The respondents indicated that they sometimes shopped at PEP (6.2\%), Sport scene (5.2\%) and Totalsports $(3.2 \%)$. The next section provides discussion of research findings of this study.

\section{Discussion}

This study provides a greater understanding of the influence of store atmospherics on the consumer behaviour of university students, an area that has received relatively little attention thus far. The results revealed that individual store atmospheric attributes -such as offering good brands, quality products, a variety of products and fashionable products -are important when university students select a clothing retail store to buy from. These findings are in line with the findings of the study by Yip, Chan and Poon (2012), which indicated that the store atmospheric attributes and consumer perceptions of these attributes are closely related and determine consumers' choice of a specific store. This study further add insight to literature by indicating that university students also consider the environmental cleanliness of the store in selecting where to shop. In addition, the findings of this study showed that university students tend to be economically active. This finding contributes to the body of knowledge by revealing that university students 'criteria for selecting a clothing retail store may be influenced by their disposable income derived from part-time jobs they hold while completing their studies. This study highlighted that university students do not consider the offering of reduced prices to be an important store attribute when they select a clothing retail store. The last two sections provide the recommendations generated from research findings and future research implications.

\section{Recommendations}

It is recommended that clothing retail stores pay closer attention to university students, as this market segment appears to be lucrative. Clothing retail store managers should ensure that they offer good brands and a variety of products so that their stores become the most popular of all the clothing retail stores. This also implies that the store managers should incorporate these attributes into their marketing communication messages. In addition, the store managers should ensure the cleanliness of the store, as students use this attribute in evaluating the clothing store of choice. Interestingly, clothing retail store managers should avoid using reduced prices as a differentiation attribute to target university students, as this attribute appears to be less important to students when they select a clothing retail store. 


\section{Future research implications}

This study was conducted in Gauteng Province of South Africa, in the City of Tshwane and the City of Johannesburg. It is recommended that a further study be conducted, including a larger number of university students in other provinces and in other countries. Ethnographic observation research is recommended to gain a deeper understanding of the shopping behaviour of university students. In addition, research on specific days, such as public holidays, or times of the month, such as month-end could also provide a deeper understanding of the consumer behaviour of university students. A further study is required to investigate the elements of both internal and external atmospheric attributes of clothing retail stores that are important to university students in other parts of South Africa.

\section{List of references}

Bevan-Dye, A.L, Garnett, A., \& De Klerk, N. (2012). Materialism, status consumption and consumer ethnocentrism amongst black generation $\mathrm{Y}$ students in South Africa. African Journal of Business Management, 6(16):55-78. http:/ / search.proquest.com/docview/1030715105?pq-origsite=gscholar

Bloemer, J., \&De Ruyter, K. (1998). On the relationship between store image, store satisfaction and store loyalty. European Journal of Marketing, 32(5/6):499-513. Available at:

http://www.emeraldinsight.com/doi/pdfplus/10.1108/03090569810216118

Cornelius, C, Natter, N., \& Faure, C. (2010). How storefront displays influence retail store image. Journal of Retailing and Consumer Services, 17(2):143-151. Available at:

http://www.sciencedirect.com/science/article/pii/S0969698909000848

Cooper, D.R. \& Schindler, P.S. (2011). Business research methods. 11th international Ed. New York, NY: McGraw-Hill.

Department of Higher Education and Training. (2015). Statistics on post-school and Training in South Africa. Available at: http://www.justice.gov.za/commissions/FeesHET/docs/2014-Statistics-Post-School-ET-SA.pdf

Department of Trade and Industry. (2016). Automotive Export Manual. Auto mechanika, South Africa. Available at: http://www.aiec.co.za/Reports/AutomotiveExportManual.pdf

Gauteng Quarterly Bulletin. (2012). The Retailindustry on the Rise in South Africa. Available at: http:// www.treasury.gpg.gov.za/Documents/QB1\%20The\%20Retail\%20Industry\%20on\%20the\%20Rise.pdf

Hernant, M. (2009). Profitability performance of supermarkets. PhD dissertation, EFI Economic Research Institute, Stockholm. Available at: https://ex.hhs.se/dissertations/220464-FULLTEXT01.pdf

Johnson, C., Banks, L. and Seo, J.I., 2016. The Effect of Product Involvement on Store Preference and Clothing Benefits Sought for African-American Female Students. Journal of Applied Business Research (JABR), 33(1), 107-114. Available at:

https://cluteinstitute.com/ojs/index.php/JABR/article/view/9871/9968

Jordaan, Y, Ehlers, L., \&Grove, J.M. (2011). Advertising credibility across media channels: perceptions of Generation $Y$ consumers. Communicare: Journal for Communication Sciences in Southern Africa 30(1):1-20. Available at:

http://journals.co.za/docserver/fulltext/comcare/30/1/comcare_v30_n1_a3.pdf?expires=1495015233\&id=id\&accna me $=58010 \&$ checksum $=6$ E95519870D3AB7B12B04A1CCAEE7E8A

Khraim, H.S, Khraim, AS, Al-Kaidah, F.M., \&Al-Qurashi, D.H. (2011). Jordanian consumer's evaluation of retail store attributes: the influence of consumer religiosity. International Journal of Marketing Studies,3(4):105-116. Available at:

http:// citeseerx.ist.psu.edu/viewdoc/download?doi=10.1.1.928.3085\&rep=rep1\&type=pdf

Mafini, C, Dhurup, M., \&Mandhlazi, L. (2014). Shopper typologies amongst a Generation Y consumer cohort and variations in terms of age in the fashion apparel market: original research. ActaCommercii, 14(1):1-11. Available at:

http://journals.co.za/docserver/fulltext/acom/14/1/acom_v14_n1_a5.pdf?expires=1495015635\&id=id\&accname=5 8010\&checksum=3763F85FAD2B79D3E4558F628DD27102

Malhotra, N.K. (2010). Marketing research: an applied orientation. 6th global edition. Upper Saddle River, NJ: Pearson.

Mari, M., \&Poggesi, S. (2013). Servicescape cues and customer behavior: a systematic literature review and research agenda. The Service Industries Journal,33(2):171-199. Available at:

http://www.tandfonline.com/doi/abs/10.1080/02642069.2011.613934

Mortimer, G., \&Clarke, P. (2011). Australian supermarket consumers and gender differences relating to their perceived importance levels of store characteristics. Journal of Retailing and Consumer Services 18(6):575-585. Available at: http://www.sciencedirect.com/science/article/pii/S0969698911000920

Mower, J.M, Kim, M., \& Childs, M.L. (2012). External atmospherics and consumer behavior: influence of landscaping and window display. Journal of Fashion Marketing and Management, 16(4):442-453. Available at:

https://www.researchgate.net/profile/Minjeong_Kim4/publication/261322950_Exterior_atmospherics_and_consu mer_behavior_Influence_of_landscaping_and_window_display/links/540fc54b0cf2df04e75a3865.pdf 
NeumanW.L. 2011. Social research Methods: Qualitative and Quantitative Approaches. $7^{\text {th }}$ ed. Pearson, South Africa.

Spence, C, Puccinelli, N.M, Grewal, D., \&Roggeveen, A.L. (2014). Store atmospherics: a multisensory perspective. Psychology and Marketing,31(7):472-488. Available at:

http:/ / onlinelibrary.wiley.com/doi/10.1002/mar.20709/epdf

Statistics South Africa. (2014). Statistical release. Available at:

http://www.statssa.gov.za/publications/P62421/P62421December2014.pdf

Statistics South Africa. (2015). Statistical release. Available

at: http:/ / www.statssa.gov.za/publications/P0305/P03052015.pdf

Statistics South Africa. (2016). Retail Trade Sales. Available at:

http://www.statssa.gov.za/publications/P62421/P62421July2016.pdf

Steinhofer, K., (2005). Young singles: a look at the grocery shopping preferences of a unique and underestimated market, survey \&analysis. Honours thesis, Western Michigan University.

Available at: http:/ / scholarworks.wmich.edu/cgi/viewcontent.cgi?article=1389\&context=honors_theses

Student Village. (2015). Student spend report. Available at:

http://www.studentmarketing.co.za/portfolio/student-spend-report-2015/.

Thang, D.C.L., \& Tan, B.L.B. (2003). Linking consumer perception to preference of retail stores: an empirical assessment of the multi-attributes of store image. Journal of Retailing and Consumer Services, 10(4):193-200. Available at:

http://www.sciencedirect.com/science/article/pii/S0969698902000061

Twenge, J.M. \& Campbell, S.M. (2008). Generational differences in psychological traits and their impact on the workplace. Journal of Managerial Psychology, 23(8):862-877. Available at:

http:/ / www.emeraldinsight.com/doi/pdfplus/10.1108/02683940810904367

Vermaak, M. and de Klerk, H.M., 2017. Fitting room or selling room? Millennial female consumers' dressing room experiences. International Journal of Consumer Studies, 41(1), pp.11-18. Available at:

http:/ / onlinelibrary.wiley.com/doi/10.1111/ijcs.12294/epdf

Visser, E.M, Du Preez, R., \&Jansevan Noordwyk, H.S. (2006). Importance of apparel store image attributes: perceptions of female consumers. South African Journal of Industrial Psychology, 32(3):49-62. Available at:

http://journals.co.za/docserver/fulltext/psyc/32/3/psyc_v32_n3_a6.pdf?expires=1495023471\&id=id\&accname=580 10\&checksum=6ADDE2F662B5648A0CC0B34BEBE792ED

Yip, T.C, Chan, K., \&Poon, E. (2012). Attributes of young consumers' favourite retail shops: a qualitative study. Journal of Consumer Marketing, 29(7):545-552. Available at:

http://journals.co.za/docserver/fulltext/psyc/32/3/psyc_v32_n3_a6.pdf?expires=1495023548\&id=id\&accname=580 10\&checksum=F6561ADE86251A06315BD8039F0409EC 